\title{
Dose-dependent Effect of T-2 Toxin on the Immunity against Newcastle Disease Virus in Chickens
}

\author{
M. WEBER ${ }^{1}$, J. FODOR ${ }^{2}$, K. BALOGH ${ }^{1}$, M. ERDÉLYI ${ }^{1}$, M. MÉZES $^{1}$ \\ ${ }^{1}$ Department of Nutrition, Szent István University, Gödöllö, Hungary \\ ${ }^{2}$ Department of Animal Physiology, Faculty of Animal Science, Kaposvár University, \\ Kaposvár, Hungary \\ Received January 13, 2006 \\ Accepted June 30, 2006
}

\begin{abstract}
Weber M., J. Fodor, K. Balogh, M. Erdélyi, M. Mézes: Dose- dependent Effect of T-2 toxin on the Immunity against Newcastle Disease Virus in Chickens. Acta Vet. Brno 2006, 75: 387-391.

The effect of 2.35 (a) and 4.18 (b) $\mathrm{mg} \cdot \mathrm{kg}^{-1}$ feed $\mathrm{T}-2$ toxin dose for 14 days on the haemagglutination inhibition titres against Newcastle disease virus was investigated in broiler chickens. The animals were divided into four groups and two separate experiments were carried out (a, b): (1) intact control group; (2) birds were fed with T-2 toxin contaminated feed and not vaccinated; (3) repeatedly vaccinated (on day 23 of age) control group which received uncontaminated feed; (4) birds were both repeatedly vaccinated and fed the T-2 toxin contaminated diet. Blood samples, from which sera titres were measured, were taken on days 7 and 14 of the experiments. It was found that heamagglutination titres were different in the two experiments even in the control (1) group because of the different efficiency of the first immunization at the hatchery. Titres on day 7 showed increases in all groups except for the group fed lower T-2 contaminated diet (a, group 2) but during the second week they increased only in the groups fed the diet with a lower dose of T-2 toxin. On the contrary, a higher dose of T-2 toxin contamination of the diet resulted in a dramatic decrease during the second week (b, groups 2 and 4). The results suggested that contrary to most of the previously published data, feeding of T-2 toxin contaminated feed with an amount of $2.35 \mathrm{mg} . \mathrm{kg}^{-1}$ did not decrease, but increase the antibody formation against attenuated Newcastle disease virus even without a second vaccination on day 1 of the experiment, whereas a higher amount of T-2 toxin $\left(4.18 \mathrm{mg} \cdot \mathrm{kg}^{-1}\right)$ decreased to day 14 after the repeated vaccination.
\end{abstract}

T-2 toxin, Newcastle disease, heamagglutination inhibition, immunity, chicken

Mycotoxins are a group of structurally diverse fungal secondary metabolites that elicit a wide spectrum of toxicological effects, such as different rate of immunosuppression (Surai and Dvorska 2005). This effect is caused by the mycotoxins, e.g. T-2 toxin, and its metabolites mainly in the thymus and spleen (Lafarge-Frays sinet et al. 1990). The $\mathrm{T}-2$ toxin impairs the natural defence mechanism, including altered parameters of humoralmediated immunity, depressed T or B lymphocyte activity (Oswald and Comera 1998) and precursors of B cells (Holladay et al. 1995). Splenic (Kamalavenkatesh et al. 2005), and thymic (Nagata et al. 2001) CD+8 and CD+4 lymphocytes represent highly sensitive targets of T-2 toxin exposure (Holladay et al. 1995). The immunosuppression of the organism results in dose-dependent, significant decrease in antibody formation in pigs ( Rafai et al. 1995), and also a manifestation of different diseases, such as swine dysentery (Sándor and Ványi 1990). Feeding T-2 toxin contaminated diet $\left(5 \mathrm{mg} \cdot \mathrm{kg}^{-1}\right)$ for 21 days caused reduced neutralizing antibody production in response to a single subcutaneous dose of vaccine against haemorrhagic gastroenteritis ( $\mathrm{R}$ a fai et al. 1989). On the contrary, a long-term treatment, a single high oral dose of T-2 toxin $\left(3 \mathrm{mg} \cdot \mathrm{kg}^{-1} \mathrm{~b} . \mathrm{w}\right.$.) but not 14-days pre-treatment with a low dose $\left(0.75 \mathrm{mg} \cdot \mathrm{kg}^{-1} \mathrm{~b}\right.$.w. $)$ have modulatory effects on the respiratory burst activity of macrophages and cell-mediated immune system and cause enhancement of resistance to E. coli and Staphylococcus aureus in mice (Cooray

Address for correspondence:

Miklós Mézes

Department of Nutrition, Szent István University

H-2103 Gödöllö, Páter Károly u. 1., Hungary
Phone: $+36-28410735$

Ffax: +36-28 410 804

E-mail: Mezes.Miklos@mkk.szie.hu

http://www.vfu.cz/acta-vet/actavet.htm 
and Jonss on 1990). On the contrary, T-2 toxin treatment at 6 and 1 days before BCG vaccination against murine pulmonary tuberculosis did not alter the efficacy of the vaccine (Ziprin and McMurray 1989). In the case of newly-hatched chickens, a 6-day pretreatment with T-2 contaminated feed had a profound negative effect on the ability of the birds to resist salmonellosis, as measured by survival (Ziprin and Elissalde 1990). It was concluded ( $\mathrm{Ram}$ et al. 1990) that T-2 toxin either at low or at high concentrations of single treatment stimulated lymphocytes. However, during a long-term treatment particularly with high doses of toxin, lymphocyte response was inhibited. No significant effect of T-2 toxin up to the concentration of $1 \mathrm{mg} \cdot \mathrm{kg}^{-1}$ feed was observed on antibody production to antigens administered by enteral or parenteral routes in chicken ( Sklan et al. 2001) and turkey (Sklan et al. 2003). No significant effect was found in turkey poults and chickens fed T-2 toxin contaminated feed even at a $10 \mathrm{mg} \cdot \mathrm{kg}^{-1}$ concentration (Richard et al. 1978). In respect of haemagglutination inhibition antibody titre to Newcastle disease, the data on experimental results showed that a daily oral dose of T-2 toxin at a dose of $1.25 \mathrm{mg} \cdot \mathrm{kg}^{-1}$ body weight (approximately $12.5 \mathrm{mg} \cdot \mathrm{kg}^{-1}$ feed) for one week did not affect the titre at the $4^{\text {th }}$ week of age (Hossain et al. 1987); on the contrary, 3 $\mathrm{mg} \cdot \mathrm{kg}^{-1} \mathrm{~T}-2$ toxin contaminated feed reduced the titre in a five-week experiment (Raju and Devegowda 2002).

\section{Materials and Methods}

Eighty chickens of the same genotype (ROSS 308 broiler cockerels), weighing $1.12 \pm 0.23 \mathrm{~kg}$, were used in the experiment. The animals were placed in cages during the trials. The temperature $\left(23 \pm 2{ }^{\circ} \mathrm{C}\right)$ of the trial room was controlled in accordance with the needs of the broiler. Feed and drinking water was available ad libitum.

The experimental animals (initial age: 23 days) were divided into four groups of 20 birds each in experiment "a" and experiment "b". With the exception of the intact control (1) and the vaccinated control (3) groups, chicken feed was contaminated with T-2 toxin at a concentration of 2.35 (a) and 4.18 (b) $\mathrm{mg}^{-\mathrm{kg}^{-1}}$ feed and was administered for 14 days. Although there is no official regulation in the European Union for the maximum allowed $\mathrm{T}-2$ toxin content in the feeds, a guideline limit of $0.5 \mathrm{mg} \cdot \mathrm{kg}^{-1} \mathrm{~T}-2$ toxin has been proposed (Eriksen and Pettersson 2004). T-2 toxin contamination in the present experiment was much higher than the maximum guideline limit level.

The partially purified toxin preparation was dissolved in acetone and then sprayed onto the compound feed (100 ml/50 kg of feed). T-2 toxin was produced experimentally on maize by Fusarium sporotrichoides, strain NRRL 3299 (Agricultural Research Service Culture Collection, National Center for Agricultural Utilization Research, Peoria, IL) as described below.

Maize was prepared in 4.2-liter wide-mouthed glass fruit jars with a cover (cotton plug between 2 linen rags) by autoclaving $800 \mathrm{~g}$ yellow maize kernels in $400 \mathrm{ml}$ water for $2 \mathrm{~h}$ at $121^{\circ} \mathrm{C}$, after soaking overnight. The prepared maize was inoculated with the 8-day-cultivated $F$. sporotrichoides strain NRRL 3299 . The culture was incubated in darkness at $24^{\circ} \mathrm{C}$ for a week, than at $8{ }^{\circ} \mathrm{C}$ for 2 weeks. After opening, the fungus-infected maize was dried at room temperature for several days, and then it was ground. The homogenized fungal culture contained T-2 toxin at a concentration of $1180.5 \mathrm{mg} \cdot \mathrm{kg}^{-1}$. Extraction and purification of toxin were carried out according to Burme ister (1971). Purity of the T-2 toxin preparation was determined by the HPLC method and exceeded $95 \%$ (Békési et al. 1997). The T-2 toxin content of the feed was measured by the HPLC technique (AOAC 1990). The amount of related trichothecenes, HT-2, T-2 triol and T-2 tetraol, were under the limit of detection $\left(<0.04 \mathrm{mg} \cdot \mathrm{kg}^{-1}\right)$.

The animals in the vaccinated groups received attenuated Newcastle disease vaccine in the form of eye drops (NobilisR ND Clone 30, Intervet International bv, Boxmeer) on day 1 of the experiment according to the producer's instruction.

The four groups (Table 1) in both experiments (a and b) were as follows: (1) intact control group; (2) birds fed T-2 toxin contaminated feed and not vaccinated; (3) vaccinated control group which received uncontaminated feed; (4) birds were both vaccinated and fed a T-2 toxin contaminated diet.

Blood samples were taken on days 7 and 14 from the cubital vein, and blood serum was analysed using haemagglutination inhibition (HI) test according to Balla (1980).

The average haemagglutation titres were calculated with geometrical mean using MS Excel 7.0 software and statistically evaluated based on the $\log _{2}$ transformation of the dilution rate as proposed by Balla (1980) by ANOVA analysis using Statistica ${ }^{\circledR} 4.5$ (Statsoft Inc., 1993) software.

The experiment was approved by the Animal Experimental Committee of the Faculty of Agricultural and Environmental Sciences of Szent István University (3/2003 MKK). 
Table 1. Treatments given in the different groups

\begin{tabular}{|c|c|c|c|}
\hline \multirow{2}{*}{ Group } & \multicolumn{2}{|c|}{ Treatment } & \multirow{2}{*}{ Vaccination } \\
\cline { 2 - 4 } & \multicolumn{2}{|c|}{ T-2 toxin concentration $\left(\mathrm{mg} \cdot \mathrm{kg}^{-1} \mathrm{feed}\right)$} & - \\
\cline { 2 - 4 } & $\mathrm{a}$ & $\mathrm{b}$ & - \\
\hline 1 & - & - & + \\
\hline 2 & 2.35 & 4.18 & + \\
\hline 3 & - & - & +18 \\
\hline 4 & 2.35 & & + \\
\hline
\end{tabular}

\section{Results}

The haemagglutination inhibition titres (Table 2) were different in the two experiments even in the control group (1), i.e. the first immunization at the hatchery had different efficacy. Haemagglutination titres were significantly different among the groups (Table 3) as an effect of vaccination, and also in groups fed a T-2 toxin contaminated diet at a lower dose $\left(2.35 \mathrm{mg} \cdot \mathrm{kg}^{-1}\right)$. It was the highest in the group which was fed a T-2 toxin contaminated diet and repeatedly vaccinated (a, group 4 ) on day 7 . On day 14 both groups fed a lower T-2 toxin contaminated diet showed a dramatic and significant increase in the haemagglutination titres both without (a, group 2) and with repeated vaccination (a, group 4). In contrast, the haemagglutination titres did not differ significantly (Table 3 ) by feeding a T-2 toxin contaminated diet at a higher dose $\left(4.35 \mathrm{mg} \cdot \mathrm{kg}^{-1}\right)$ on day 7 but it was also the highest in the group fed T-2 toxin contaminated diet and repeatedly vaccinated (Table 2) against Newcastle disease virus (b, group 4). On day 14 after the repeated vaccination haemagglutination titres were significantly different among the groups but showed opposite tendency in the groups fed T-2 toxin contaminated diet at a higher dose than at a lower one (Table 2). Namely the haemagglutination titre decreased in these groups as compared to the value on day 7 either without (b, group 2) or with repeated vaccination (b, group 4).

Table 2. Effect of T-2 toxin contaminated feed and/or vaccination against Newcastle disease on haem agglutination inhibition titres in blood sera of chicken

\begin{tabular}{|c|c|c|c|}
\hline \multirow[t]{2}{*}{ Group } & \multirow{2}{*}{$\begin{array}{l}\text { Period after repeated } \\
\text { vaccination } \\
\text { (days) }\end{array}$} & \multicolumn{2}{|c|}{ HAG titre } \\
\hline & & Geometric mean & $\begin{array}{c}\log _{2} \\
\text { mean } \pm \mathrm{SD}\end{array}$ \\
\hline \multicolumn{4}{|c|}{ Experiment (a)- $2.35 \mathrm{mg} \cdot \mathrm{kg}^{-1} \mathrm{~T}-2$ toxin in feed } \\
\hline \multirow[t]{2}{*}{1} & 7 & 3.2 & $1.68 \pm 0.00$ \\
\hline & 14 & 44.6 & $5.48 \pm 4.38$ \\
\hline \multirow[t]{2}{*}{2} & 7 & 2.7 & $1.43 \pm 0.96$ \\
\hline & 14 & 289.6 & $8.18 \pm 1.00$ \\
\hline \multirow[t]{2}{*}{3} & 7 & 18.1 & $4.18 \pm 3.00$ \\
\hline & 14 & 172.2 & $7.43 \pm 1.50$ \\
\hline \multirow[t]{2}{*}{4} & 7 & 102.4 & $6.68 \pm 1.22$ \\
\hline & 14 & 409.6 & $8.68 \pm 0.00$ \\
\hline \multicolumn{4}{|c|}{ Experiment (a) $-4.18 \mathrm{mg} \cdot \mathrm{kg}^{-1} \mathrm{~T}-2$ toxin in feed } \\
\hline \multirow[t]{2}{*}{1} & 7 & 2.0 & $1.00 \pm 0.00$ \\
\hline & 14 & 16.0 & $4.00 \pm 4.12$ \\
\hline \multirow[t]{2}{*}{2} & 7 & 9.2 & $3.20 \pm 0.44$ \\
\hline & 14 & 2.0 & $1.00 \pm 3.04$ \\
\hline \multirow[t]{2}{*}{3} & 7 & 57.0 & $8.38 \pm 0.57$ \\
\hline & 14 & 445.7 & $8.80 \pm 0.83$ \\
\hline \multirow[t]{2}{*}{4} & 7 & 128.0 & $7.00 \pm 1.26$ \\
\hline & 14 & 45.3 & $5.50 \pm 1.51$ \\
\hline
\end{tabular}


Table 3. ANOVA analysis of HAG titres expressed in $\log _{2}$ of the dilution rate

\begin{tabular}{|c|c|c|c|c|c|}
\hline $\begin{array}{c}\text { Period after } \\
\text { the repeated } \\
\text { vaccination (days) }\end{array}$ & $\begin{array}{c}\text { Toxin dose } \\
(\mathrm{mg} / \mathrm{kg} \text { feed })\end{array}$ & Mean square & $\begin{array}{c}\text { Mean } \\
\text { square error }\end{array}$ & $\begin{array}{c}\mathrm{F}(\mathrm{df1} 1.2) \\
1.9\end{array}$ & $\mathrm{p}$-level \\
\hline 7 & 2.35 & 75 & 7.91453 & 9.476242 & 0.013175 \\
\hline 14 & 2.35 & 432 & 1.230769 & 351 & 0.0000000161 \\
\hline 7 & 4.18 & 3 & 11.65812 & 0.257331 & 0.624156 \\
\hline 14 & 4.18 & 108 & 12.76923 & 8.457831 & 0.017361 \\
\hline
\end{tabular}

\section{Discussion}

Mycotoxins, particularly trichothecene toxins, were declared as immunosuppressive compounds in animals (Surai and Dvorska 2005), but certain previous experiments did not find a significant effect of T-2 toxin on antibody production in reaction to antigens administered by enteral or parenteral routes in chickens (Sklan et al. 2001) and turkeys (Sklan et al. 2003) up to $1 \mathrm{mg} \cdot \mathrm{kg}^{-1}$ feed. The same non-significant effect was found in turkey poults and chickens fed T-2 toxin contaminated feed even at a $10 \mathrm{mg} \cdot \mathrm{kg}^{-1}$ concentration ( $\mathrm{Rich}$ ard et al. 1978). In respect of haemagglutination inhibition antibody titre to Newcastle disease, data on the experimental results showed that T-2 toxin with $1.25 \mathrm{mg} \cdot \mathrm{kg}^{-1}$ body weight (approximately $12.5 \mathrm{mg} \cdot \mathrm{kg}^{-1} \mathrm{feed}$ ) did not affect the titre at the $4^{\text {th }}$ week of age (Ho s sain et al. 1987); on the contrary, $3 \mathrm{mg} \cdot \mathrm{kg}^{-1} \mathrm{~T}-2$ toxin contaminated feed reduced the titre in a five-week experiment (Raju and Devegowda 2002).

The results of the present study showed that a T-2 toxin contaminated feed has a marked effect on the immunity against Newcastle disease in a dose- and time-dependent manner. The immune system was activated and haemagglutination titres were increased, by a lower level of T-2 toxin $\left(2.35 \mathrm{mg} \cdot \mathrm{kg}^{-1}\right)$ loading for 14 days even without repeated vaccination on day 23 of age. On the contrary, using a higher dose $\left(4.18 \mathrm{mg} \cdot \mathrm{kg}^{-1}\right)$ of contamination of T-2 toxin haemagglutatination titres increased up to day 7 , but decreased dramatically during the next week. These results suggest that the effect of T-2 toxin on the immune response in chicken depends on the age of animals, amount of mycotoxin, also the period of feeding the T-2 toxin contaminated diet. Summarizing the results, it can be concluded that the wellknown immunosuppressive effect manifested only at a high level of contamination (4.18 $\left.\mathrm{mg} \cdot \mathrm{kg}^{-1}\right)$ and after a longer period (14 days) of time.

\section{Účinek různých dávek T-2 toxinu u kuřat na tvorbu protilátek proti viru Newcastleské nemoci (ND)}

U brojlerových kuřat byl zkoumán vliv T-2 toxinu, v dávce 2,35 (a) a 4,18 (b) mg.kg-1 krmiva po dobu 14ti dní, na titry protilátek v hemaglutinačně inhibičním testu u viru Newcastleské choroby. Ptáci byli rozděleni do dvou skupin a byly provedeny dva samostatné pokusy (a,b): (1) intaktní kontrolní skupina; (2) ptákủm bylo podáno krmivo s T-2 toxinem, ale nebyli vakcinováni, (3) kontrolní skupina opakovaně vakcinovaných (23. den po vylíhnutí), která nedostala žádné krmivo s T-2 toxinem; (4) ptáci byli vakcinováni a bylo jim podáno krmivo s T-2 toxinem. Sedmý a 14. den experimentu byly odebrány vzorky krve k zjištění titrů protilátek ze séra. Při každém ze dvou pokusů byly zjištěny různé hemaglutinační titry a to i u kontrolní (1) skupiny vzhledem k rozdílné účinnosti první imunizace v líhni. Sedmý den vzrostly titry u všech skupin, kromě té krmené směsí s nižší dávkou T-2 toxinu (a, skupina 2). Druhý týden se titry zvýšily už jen u skupiny, které byla podána nižší dávka T-2 toxinu. Naproti tomu vyšší dávka T-2 toxinu v krmivu vedla k významnému snížení během druhého týdne (b, skupiny 2 a 4). Výsledky ukazují, že navzdory mnoha předešlým publikacím, krmení kuřat krmivem kontaminovaným T-2 toxinem v množství 
2,35 mg. $\mathrm{kg}^{-1}$ nesnížilo, ale naopak zvýšilo tvorbu protilátek proti atenuovanému viru Newcastleské nemoci dokonce i bez druhé vakcinace $\mathrm{v} 1$. den pokusu, zatímco vyšší množství T-2 toxinu $\left(4,18 \mathrm{mg} \cdot \mathrm{kg}^{-1}\right)$ ji do 14 . dne po opakované vakcinaci snížilo.

\section{References}

AOAC 1990: Official methods of analysis of the Association of Official Analytical Chemists, $15^{\text {th }}$ ed., Association of Official Analytical Chemists, Arlington, Va.

BALLA L 1986: Use of standardized haemagglutination inhibition (HI) test for checking the immunity against Newcastle disease. I. Experiments to standardize the HI test (In Hungarian). Magy Állatorv Lapja 41: 98-103

BÉKÉSI L, HORNOK S, SZIGETI G, DOBOS-KOVÁCS M, SZÉLL Z, VARGA I 1997: Effect of F-2 and T-2 fusariotoxins on experimental Cryptosporidium baileyi infection in chickens. Int J Parasitol 27:1531-1536

BURMEISTER HR 1971: T-2 toxin production by Fusarium tricinctum on solid substrate. Appl Microbiol 21: 739-742

COORAY R, JONSSON P 1990: Modulation of resistance to mastitis pathogens by pre-treatment of mice with T2 toxin. Food Chem Toxicol 28: 687-692

ERIKSEN GS, PETTERSSON H 2004: Toxicological evaluation of trichothecenes in animal feed. Anim Feed Sci Technol 114: 205- 239

HOLLADAY SD, SMITH BJ, LUSTER MI 1995: B-lymphocyte precursor cells represent sensitive targets of T2 mycotoxin exposure. Toxicol Appl Pharmacol 131: 309-315

HOSSAIN MI, GUPTA RKP, BHATIA KC, MISHRA UK 1987: Haemagglutination inhibition titres to Newcastle disease virus in T-2 mycotoxin administered chicks. Bangladesh Vet J 21: 99-102

KAMALAVENKATESH P, VAIRAMUTHU S, KALACHANDRAN C, MANOHAR BM, RAJ GD 2005: Immunopathological effect of the mycotoxins cyclopiazonic acid and T-2 toxin on broiler chicken. Mycopathologia 159: 273-279

LAFARGE-FRAYSSINET C, CHAKOR K, LAFONT P, FRAYSSINET C 1990: Transplacental transfer of T-2 toxin: pathological effects. J Exp Pathol Toxicol Oncol 10: 64-66

NAGATA T, SUZUKI H, ISHIGAMI N, SHINOZUKA J, UETSUKA K, NAKAYAMA H, DOI K. 2001: Development of apoptosis and changes in lymphocytes subsets in thymus, mesenteric lymph nodes and Peyer's patches of mice orally inoculated with T-2 toxin. Exp Toxicol Pathol 53: 309-315

OSWALD JP, COMERA C 1998: Immunotoxicity of mycotoxins. Rev Med Vet 149: 585-590

RAJU MVLN, DEVEGOWDA G 2002: Esterified-glucomannan in broiler chicken diets contaminated with aflatoxin, ochratoxin and T-2 toxin: evaluation of its binding ability (in vitro) and efficacy as immunomodulator. Asian-Australasian J Anim Sci 15: 1051-1056

RAFAI P, TUBOLY S, TURY E 1989: Effect of T-2 fusariotoxin on adrenocortical function and some immunological parameters in growing pigs (In Hungarian). Magy Allatorv Lapja 44: 299-303

RAFAI P, TUBOLY S, BATA A, TILLY P, VÁNYI A, PAPP Z, JAKAB L, TURY E 1995: Effect of various levels of T-2 toxin in the immune system of growing pigs. Vet Rec. 136: 511-514

RAM GC, RAO MVS, BANSAL MP 1990: Inhibition of blastogenesis in cattle lymphocytes by T-2 toxin and its restoration with interleukin-2 (IL-2). Ind J Anim Sci 60: 273-278

RICHARD JL, CYSEWSKI SJ, PIER AC, BOOTH GD (1978): Comparison of effects of dietary T-2 toxin on growth, immunogenic organs, antibody formation, and pathologic changes in turkeys and chickens. Am J Vet Res 39: 1674-1679

SANDOR G, VANYI A 1990: Mycotoxin research in the Hungarian Central Veterinary Institute. Acta Vet Hung 38: $61-68$

SKLAN D, KLIPPER E, FRIEDMAN A, SHELLY M, MAKOVSKY B 2001: The effect of chronic feeding of diacetoxyscirpenol, T-2 toxin, and aflatoxin on performance, health and antibody production in chicks. J Appl Poult Res 10: 79-85

SKLAN D, SHELLY M, MAKOVSKY B, GEYRA A, KLIPPER E, FRIEDMAN A 2003: The effect of chronic feeding of diacetoxyscirpenol and T-2 toxin on performance, health, small intestinal physiology and antibody production in turkey poults. Br Poult Sci 44: 46- 52

SURAI PF, DVORSKA JE (2005): Effects of mycotoxins on antioxidant status and immunity. In: DIAZ DE (Ed): The Mycotoxin Blue Book, Nottingham University Press, Nottingham, pp. 93-138

ZIPRIN RL, MCMURRAY DN 1989: Influence of T-2 toxin on BCG vaccine efficacy against murine pulmonary tuberculosis. Vet Hum Toxicol 31: 213-217

ZIPRIN RL, ELISSALDE MH 1990: Effect of T-2 toxin on resistance to systemic Salmonella typhimurium infection of newly hatched chickens. Am J Vet Res 51: 1869-1872 